Models of Platform Regulation 



\title{
Rights and Duties of Online Platforms
}

\author{
Judit Bayer
}

Abstract: One of the two extreme ends of regulatory approaches to online platforms treats platforms as independent governors of speech, the other treats platforms as mere conveyors of third-party content. This paper highlights regulatory provisions and court cases that represent one or the other extreme. However, it ultimately found that the approaches are mixed and some instruments, like the draft Digital Services Act, combine both approaches consciously. While the different approaches may not be reconcilable in all cases, umbrella approaches, such as competition law and international human rights law, may set a higher-level framework to bring more consistency.

Keywords: online platforms, human rights, content governance, moderation, Digital Services Act, horizontal effect of human rights.

\section{Chapter 1. Introduction}

In the recent decade, social media platforms have gained influence over the public discourse across the globe. Their operation impacts various human rights, primarily freedom of expression and the right to information, but also others like privacy, dignity, the right to free elections, and potentially more.

These private actors do more than just transmit content; with their moderating, ranking, prioritising, and targeting actions, they govern and tailor the public discourse. ${ }^{1}$ This activity is built into their design, and they could not operate without performing some form of selection and ranking. In addition to the strictly necessary moderation, further 'optimising'

1 Tarleton Gillespie, Custodians of the Internet: Platforms, Content Moderation, and the Hidden Decisions That Shape Social Media (New Haven: Yale University Press, 2018). 
is carried out to maximise advertising revenues, increase user engagement, ${ }^{2}$ and maintain a civilised communicative environment. Thus, they govern content through their infrastructural design on the one hand and their moderation choices on the other.

They do so without being bound by human rights safeguards or accountable for their tailoring actions. ${ }^{3}$ The largest social media platforms make considerable efforts to increase their transparency, cooperate with policymakers, and publicly impress that their content moderation choices are governed by moral values. However, when it comes to conflicting human rights, deciding whether content is legal or not becomes more complex. Often, this question can be answered relatively easily (copyright, terrorism, child abuse), although there are borderline cases and controversies even in these fields. One of the most cited examples of social media censorship concerned the photograph that became known as the 'Napalm girl', showing desperate people running from obvious traces of a (Napalm) bomb attack, among them a naked female child. The removal of this picture attracted considerable public outcry and closer scrutiny of the moderation principles. ${ }^{4}$ Other types of illegal content cannot be interpreted without knowing the context, such as violation of reputation or certain forms of hate speech, and are more difficult to judge.

There is a variety of approaches to liability for third-party content around the globe, depending partly on the subject matter of the content or on the legal branch, but all provide a certain level of immunity. The American approach provides platforms with immunity for third-party content without conditions ${ }^{5}$ (except if the subject matter is copyrighted

2 Hannah Schwär and Qayyah Moynihan, „Instagram and Facebook are intentionally conditioning you to treat your phone like a drug”, Business Insider, 5 April 2020, https:/www.businessinsider.com/facebook-has-been-deliberately-designed-to -mimic-addictive-painkillers-2018-12.

3 Rikke Frank Jørgensen and Lumi Zuleta, "Private governance of freedom of expression on social media platforms: EU content regulation through the lens of human rights standards," Nordicom Review 41 no. 1 (2020): 51-67, https://doi.org/ 10.2478/nor-2020-0003.

4 Tarleton Gillespie, Custodians of the Internet: Platforms, Content Moderation, and the Hidden Decisions That Shape Social Media (New Haven: Yale University Press, 2018), 7. See also: Kate Klonick, "The Most Important Lesson from the Leaked Facebook Content Moderation Documents,” Slate.com, June 29, 2017, https://slate.com/technology/2017/06/the-most-important-lesson-to-learn-about-face book-content-moderation.html.

5 Communications Decency Act (CDA) 1996, $\$ 230$. 
content when the notice-and-takedown regime applies). ${ }^{6}$ The European E-Commerce Directive ${ }^{7}$ provides conditional exemptions from liability. The Digital Services Act (DSA) $)^{8}$ has followed this approach, requiring the removal of illegal content. It has also developed procedural safeguards partly following the example of the German Network Enforcement Act (NetzDG). ${ }^{9}$

However, the real question, and the focus of this article, is the extent of platforms' freedoms regarding lawful content. What do they really do and is that activity subject to any legal regulation? The draft Digital Service Act defines 'online platforms' as hosting providers which also disseminate content (Article 2.h) DSA). The word 'disseminate', however, does not accurately reflect the content organising activity that platforms do; they rank, prioritise, deprioritise, and label content. Ironically, this organising activity is the main service platforms provide, beyond mere hosting of content, and it is precisely that which makes them so unique. Unfortunately, this activity is currently not transparent and there is no accountability for platforms. ${ }^{10}$ The draft Digital Services Act does not seem to change this. It merely provides for compulsory self-regulation in the field of lawful but harmful content and other risks. Similarly, the Audiovisual Media Services Directive has provided that video-sharing platforms should adopt and apply pro-active self- and co-regulatory schemes to tackle harmful content (Article 28b AVMS Directive). ${ }^{11}$

Deprioritising or labelling and other forms of moderation are based on platforms' community guidelines. While these softer methods interfere less with the individual human right to free expression, they equally interfere with the public discourse. There is "a right to speech, but no right to reach", meaning the freedom is no guarantee that content reaches a high number of users. This catchy phrase disguises a critical aspect of social media platforms' power. First, if a dominant market player chooses to

6 Digital Millenium Copyright Act (DMCA) 1998.

7 Directive 2000/31/EC of the European Parliament and of the Council of 8 June 2000 on certain legal aspects of information society services, in particular electronic commerce, in the Internal Market ('Directive on electronic commerce').

8 Digital Services Act amending Directive 2000/31/EC COM/2020/825 final.

9 Netzwerkdurchsetzungsgesetz - NetzDG (2017), https://www.gesetze-im-internet. de/netzdg/BJNR335210017.html.

10 (Commercial platforms like eBay etc., provide more transparent ranking criteria to their users than social media platforms.)

11 Audiovisual Media Services Directive, Directive 2010/13/EU. 
deprioritise an item of content, it effectively suppresses it. ${ }^{12}$ With this, the platform will have interfered with the right to freedom of expression of the individual speaker (whether this is relevant in the light of the horizontal effect of human rights will be discussed in Chapter 3.b). Second, when such deprioritising is done on a large scale and/or over a long period of time, its accumulative effect has a potential to damage public discourse which impacts societies' democratic processes.

Whether and how the community standards and algorithmic moderation of giant social media platforms influence the public discourse - for example, by pushing some items onto the agenda and suppressing others - is not subject to supervision or accountability. The draft Digital Services Act envisages a co-regulatory scheme to provide for, at a minimum, consultation in setting the goals (Article 35 DSA). Whether the declared goals are fulfilled would be the subject of transparency requirements, but without legal consequences.

\section{Chapter 2. The regulatory frames of platforms' powers}

To what extent should platforms independently decide on content standards, including what should remain and receive attention online and what should be suppressed or removed? Should it be a platform's privilege to define content standards and the agenda, and govern the public discourse, similarly to traditional media companies? We are witnessing this happening; it has organically developed this way. The comparison with traditional media companies is tempting but inaccurate in several aspects. First, social media platforms do not publish their own content, and their users are not paid journalists representing the media companies' agenda. Still, with the help of algorithms, companies can prioritise those views they would like to promote. Second, the largest online platform companies reach and engage massively more people than traditional newspapers or broadcasters. ${ }^{13}$ The largest newspaper company in the United States (US), based on circulation, reached just over 8.59 million persons

12 Molly K. Land. "Toward an international law of the internet", Harvard International Law Journal 54, no. 2 (2013): 393.

13 “Top 10 U.S. Newspapers by Circulation”, Agility PR, last modified January 2021, https:/www.agilitypr.com/resources/top-media-outlets/top-10-daily-american-new spapers/. 
in $2020,{ }^{14}$ slightly less than the largest single newspaper in the world, Yomiuri Shimbun, with 9.1 million subscribers in the same year. ${ }^{15}$ There is no aggregated data on the reach of international newspaper corporations, such as the Murdoch empire. In any case, it is hard to compete with Facebook's 190 million users in the US and 2.7 billion active users globally. ${ }^{16}$

As a consequence of a series of policy decisions, or more likely of their absence, social media lacks accountability. In contrast, traditional media, particularly broadcasting, is subject to significant restrictions regarding content, advertising, and in several countries, ownership. Current regulatory attempts in the United Kingdom (UK) and the European Union (EU) seek to find the middle road and acquire a certain level of supervision over content regulation decisions without making platforms accountable for individual content items. However, advertising and ownership regulation is not currently on the legislative agenda.

Online platforms might be further compared to cable or satellite companies (distributors) which are also subject to legal restrictions in selecting content to be transmitted, as well as their contracting conditions with the end-users. Differences again lie in the providers of content (media companies as responsible publishers in the case of distributors, and lay persons in the case of social media) and the volume of content. Moreover, platforms have a greater potential to govern the display of content than distributors.

This paper examines the relationship between social media platforms' freedom to govern content and the state's regulatory intervention into this freedom. From a comparative perspective, I set the hypothesis that two schools of thoughts (and policy approaches) exist, which represent the two ends of a spectrum:

a) Less freedom to platforms: they are supposed to convey content and only remove what they are obliged to by law, i.e., illegal content. They must respect procedural rights and - in an extreme interpretation of the limits - do not enjoy unlimited freedom in defining their Terms of Services, which must respect consumer protection principles, if not

14 "Leading newspaper companies in the United States in 2020, by total circulation", Statista, June 2020, https://www.statista.com/statistics/234685/leading-newspaper -companies-in-the-us-by-total-weekday-circulation/.

15 “Top Daily Newspapers in the World", Infoplease, last modified April 162020 , https:/www.infoplease.com/culture-entertainment/journalism-literature/top-ten-t op-daily-newspapers-world.

16 "Facebook by the Numbers: Stats, Demographics \& Fun Facts", Omnicore, last modified January 6 2021, https:/www.omnicoreagency.com/facebook-statistics/. 
fundamental rights. In other words, they might be obliged to carry certain content and be prohibited from removing it. This almost treats platforms as common carriers of content that is protected by the right to freedom of expression.

b) Wider freedom to platforms: they enjoy unconditional immunity for third party content and freedom to govern their premises, and can thereby practically regulate users' speech.

During my research, I found that these two categories are not entirely distinct. Further, some court decisions or policy instruments carry elements of both schools. Analysis of these might contribute to a crystallisation of platforms' rights and scope of competence in the formation of public discourse.

Ultimately, the investigation boils down to two simple questions. Who has the upper hand in forming the informational environment: platforms, users, or governments? And what needs to be done to create a balanced division of power, bearing in mind that the rights of one platform user often conflict with those of another user?

To shed light on the underlying legal concepts that may inform this debate, I will explore the developing discussion about the horizontal effect of human rights on private enterprises. There is agreement that states are obliged to ensure the enjoyment of human rights, but this agreement does not include private enterprises. However, an emerging debate can be observed among academic authors and international bodies in this respect, advocating for a more inclusive interpretation of the human rights obligations of private enterprises. This debate will be examined below.

The paper primarily focuses on the European Union with a comparative analysis of relevant case law and legislation, most notably from Germany and the United States. International and self-regulative norms are also drawn into the analysis.

\section{Chapter 2.a. Stricter interpretation of platforms' roles and responsibilities}

According to my hypothesis, a stricter interpretation of platforms' freedoms sees platforms' competences limited to the deletion of illegal content. This section of the paper will discuss a collection of laws and decisions representing this strict approach towards platforms' roles.

According to this approach, legislative instruments may limit platforms' freedom in defining which content to carry and which to remove or deprioritise. A typical manifestation of the strict policy approach towards 
platforms' responsibility is the German Network Enforcement Act (NetzDG). This orders online platforms to remove, upon notification, content that violates the Criminal Code's listed hate speech prohibitions within a short deadline. Large online platforms are obliged to create a procedure for removal which respects users' procedural rights and are subject to transparency obligations, including reporting on their activities. ${ }^{17}$ (More on this law can be seen in this volume by Hemmert-Halswick).

The other side of the coin is to oblige platforms to also carry certain content. For example, the German new media law provision in the German Media Treaty (MStV) prohibits platforms from discriminating against journalistic content. ${ }^{18}$ Furthermore, the draft DSA provides for crisis protocols to be created by very large online platforms and facilitated by the European Commission (Article 37). These would include, among others, "displaying prominent information on the crisis situation provided by Member States' authorities or at Union level". Currently, there are other crisis communication measures within the European body of laws in the realm of cybersecurity incidents ${ }^{19}$ and food safety. ${ }^{20}$ However, even taken together, these measures fall short of a legal obligation for any provider to carry messages or to prioritise them.

Another element of the strict approach to regulation would be that platforms should carry all lawful content without discretion, as held by the Higher State Court (Oberlandesgericht, OLG) München and confirmed by the OLG Berlin. ${ }^{21}$ The Court held that Facebook was not allowed to apply a stricter standard than the state; therefore, comments that were not illegal were not to be deleted. This was considered an obligation arising from Facebook's Terms of Service (TOS) as opposed to the Constitution. The TOS violated the principle of good faith when it stated that the platform may remove any content. Additionally, the fact that Facebook alone decided whether a post violated its guidelines was contrary to the

17 NetzDG (2017), https://www.gesetze-im-internet.de/netzdg/BJNR335210017. html.

18 German Media State Treaty (MStV), $\$ 94$.

19 Commission Recommendation (EU) 2017/1584, 22-23.

20 Commission Implementing Decision (EU) 2019/300 of 19 February 2019 establishing a general plan for crisis management in the field of the safety of food and feed, Annex I, (Title 2, paragraph 5) "Dissemination of key messages via social media and other tools (specific webpage for example) including, when necessary, the EFSA Communication Experts Network)".

21 OLG München, 24.08.2018 - 18 W 1294/18, NJW 2018, 3115; LG Berlin, 16.01.2018 - 16 O 341/15, GRUR-RR 2018, 372. 
Civil Code, which provided for equal rights of the contracting parties. ${ }^{22}$ Blocking the user account was interpreted as a unilateral termination or suspension of the contract, which is generally unlawful. ${ }^{23}$ In a similar decision against Twitter, the OLG Dresden Court found that Twitter's TOS, which said that they might revise their TOS from time to time, was unlawful. ${ }^{24}$ In the Court's view, this could mean that they can change any rule, even the free nature or provision of their services. Importantly, the German Civil Code includes clear limitations on the content of General Terms and Conditions, ${ }^{25}$ among which unilateral amendment of the terms is invalid. ${ }^{26}$

Besides, the content in the Twitter case was not illegal; it was satirical. Therefore, even if it violated the TOS, it was covered by freedom of expression. The OLG Dresden Court later held that the indirect third party effect' or indirect horizontal effect of fundamental rights, an established principle in German constitutional law (see more on this below), should ensure that satirical expressions do not result in a deletion of the account. Although this horizontal effect does not directly oblige private entities to ensure fundamental rights in relation to other private entities, it should ensure a certain level of respect in civil law relationships, particularly regarding the general terms and the ambiguous legal terms of civil law. ${ }^{27}$ With this argumentation, the OLG Dresden went further than the OLG München, which established its verdict on the Civil Code's provisions on equal rights of the parties and limitations of the General Terms and Conditions.

In another case, the Regional Court of Frankfurt held that the blocking and deletion of a statement is not justified if the statement is covered by freedom of expression. ${ }^{28}$ The court referred to the indirect third-party effect of fundamental rights. In this case, Facebook had removed a political

22 BGB [German Civil Code] (87 $7^{\text {th }}$ edition, 2021), $\ 241$ para. 2.

23 R. Schwartmann and R. L. Mühlenbeck, „NetzDG und das virtuelle Hausrecht sozialer Netzwerke“ (2020) ZRP, 170.

24 LG Dresden, 12. 11. 2019 - 1a O 1056/19, MMR 2020, 247; OLG Dresden, 07.04.2020 - 4 U 2805/19, MMR 2020, 626.

25 BGB, $₫ 305-310$.

26 BGB, $\$ 308$, no. $4-5$.

27 J. Merck, "OLG Dresden: Twitter darf Accounts nicht ohne ausreichenden Grund sperren“, LHR, June 29 2020, https:/www.lhr-law.de/magazin/social-media-recht/ olg-dresden-twitter-darf-accounts-nicht-ohne-ausreichenden-grund-sperren/.

LG Frankfurt am Main, 14.05.2018 - 2-03 O 182/18, MMR 2018, 545. 
opinion that did not amount to hate speech and suspended the user's account for 30 days. ${ }^{29}$

In other judgments, the German courts found that Facebook's community guidelines adequately respected human rights principles. ${ }^{30}$ Despite the positive findings in favour of the platform, this signals an anticipation that if platforms fail to adequately respect human rights, their decisions will be invalidated. Therefore, these cases are also relevant to the "strict" approach, albeit they represent a more relaxed expectation than that permitting the removal of illegal content only: if there is general respect for human rights, then even lawful content may be removable.

However, German jurisprudence regarding the human rights obligations of platforms is not consistent, as demonstrated by a 2021 case decided in Braunschweig at first and second instances. ${ }^{31}$ The court of first instance declared that as an operator of a social network with considerable market power, Facebook owed an enhanced duty to respect fundamental rights. It held that the basic legal content of the fundamental rights should also prevail in private law, particularly the general clauses and other terms that need to be interpreted in light of the fundamental rights. Therefore, the terms of the contract should be interpreted in an opinion-friendly manner. At the same time, it also recognised Facebook's fundamental rights to pursue business and to property (Articles 12 and 14 of the German Basic Law) and held that Facebook was not obliged to publish all expressions of opinion without discretion, even if they were protected by freedom of expression. However, the content in question in the said case did not amount to hate speech, and the removal was therefore unjustified. Yet the appeal court disagreed; it denied that Facebook has a heightened obligation to respect fundamental rights or that its guidelines would need to be interpreted in an opinion-friendly manner. Moreover, it held that even state authorities are not required to provide a means for expressing and disseminating opinions. Certainly, there is no such obligation for pri-

29 The translation of the removed opinion is: "The pseudo-left $\mathrm{T}$ is a warmonger first class! Wasn't it this hate speech that recently whistled that you were about to go bankrupt? NO LOSS! is my opinion!"

30 OLG Karlsruhe, 25.06.2018 - 15 W 86/18, NJW 2018, 3110; LG Heidelberg, 28.8.2018 - 1 O 71/18, MMR 2018, 773.

31 OLG Braunschweig, 05.02.2021 - 1 U 9/20, decision of second instance court, preceded by the first instance decision of LG Braunschweig, 11.12.2019 - 9 O 4199/18. The statement in question was: "Den Schrott versenken, das ist ein illegales Schlepperschiff!" translated as "Sink the scrap, this is an illegal tugboat!" in response to the news headline: "Private rescue ship "Aquarius" returns to the Mediterranean off Libya.” 
vate companies. The Appeal Court statement that Facebook does not even have a dominant position in the dissemination of opinions demonstrates the level of controversy. The Appeal Court explained that the basic rights are not directly applicable between private parties but only have indirect third-party effect in private law. Finally, it found that the incriminating expression amounted to hate speech, and the removal was justified.

This leads us to the second chapter which examines the more relaxed approach towards platforms' responsibility, allowing them more freedom to decide.

\section{Chapter 2.b. Wider freedom to platforms}

From this angle, state interference is undesirable and private governance more trustworthy. Social media platforms are regarded as legitimate governors of their premises and users' expressions. The clearest manifestation of this is Section 230 of the Communications Decency Act of the United States or, more specifically, its "Good Samaritan" provision. The rule provides immunity to any actor for the speech of third persons, even if they moderate the content for reasons of decency. ${ }^{32}$ Subsection (c) (2) explicitly says "whether or not such material is constitutionally protected", by which it presumes that constitutionally protected material may also be removed or restricted. Platforms are free to carry illegal content without risk of being liable (until a court order or a specific act ${ }^{33}$ obliges them to remove it), and they are free to remove lawful content, similarly. This freedom is even more robust in light of the state action doctrine ${ }^{34}$ according to which private institutions do not have constitutional obligations, only the

32 CDA $\$ 230$. (c) (1) "No provider or user of an interactive computer service shall be treated as the publisher or speaker of any information provided by another information content provider." (c)(2) "any action voluntarily taken in good faith to restrict access to or availability of material that the provider or user considers to be obscene, lewd, lascivious, filthy, excessively violent, harassing, or otherwise objectionable, whether or not such material is constitutionally protected."

33 The Digital Millenium Copyright Act provides for the takedown of copyrighted content upon notice.

34 Stephan Jaggi, "State Action Doctrine”, Oxford Constitutional Law, last modified October 2017, https://oxcon.ouplaw.com/view/10.1093/law-mpeccol/law-mpeccol -e473; see also: "State Action Requirement", LLI, https://www.law.cornell.edu/we $\mathrm{x} /$ state_action_requirement. 
state does. ${ }^{35}$ Some US policy experts question this convenience in the hope of gaining more control over platforms. ${ }^{36}$ The debate encompasses the two competing views discussed in this paper. One argument is that with freedom should come responsibility, ${ }^{37}$ however, control would furnish the government with power over speech, which is another cause for concern and contrary to American First Amendment tradition.

Under this more liberal approach, it is clear that platforms have the freedom to decide about content removal, content prioritising, deprioritising, and labelling according to their own standards (whether transparently or not is another question). However, it is still unknown whether this competence would also include curating content or generating their own content. 'Curated' content presents walled gardens meant to provide controlled, trustworthy information to the public. This was used by Twitter, Facebook, Mozilla and TikTok in the fight against the COVID-19 infodemic to present authentic scientific information to the public. This curated content - which has features of a digest or a magazine - represents a service different from the usual activity of ranking and prioritising. Selecting and presenting the content in one bundle includes editorial decisions. As a response to the pandemic, these can be regarded as extraordinary, crisisrelated content offers. ${ }^{38}$ The question is, does this practice have a place

35 Amelie Heldt, "The President and Free Speech: Consequences of Twitter's FactChecking Indication”, Internet Policy Review, June 4, 2020, https://policyreview.i nfo/articles/news/president-and-free-speech-consequences-twitters-fact-checking-in dication/1483.

36 Ilya Banares, Rebecca Kern and Naomi Nix, "Facebook, Twitter, Google CEOs Split Over Social Media's Shield”, Bloomberg, March 24 2021, https://www.bloo mberg.com/news/articles/2021-03-24/zuckerberg-supports-section-230-reform-a head-of-house-hearing. Among others, the conservative Chairman of the Federal Communications Commission, Ajit Pai - the same person responsible for erasing the rule on network neutrality in the US - supports the plan to limit Section 230's scope. Jessica Guynn, "Trump vs. Big Tech: Everything you need to know about Section 230 and why everyone hates it”, USA Today Tech, https://eu.usatoday.co $\mathrm{m} /$ story/tech/2020/10/15/trump-section-230-facebook-twitter-google-conservative -bias/3670858001/.

37 Spelled out by Nancy Pelosi, Speaker of the House in an interview: "But I do think that for the privilege of 230, there has to be a bigger sense of responsibility on it”. https://www.vox.com/2019/4/12/18307957/nancy-pelosi-donald-trump-twit ter-tweet-cheap-freak-presidency-kara-swisher-decode-podcast-interview.

38 See also in: Judit Bayer, Bernd Holznagel, Katarzyna Lubianiec, et al., "Disinformation and propaganda: impact on the functioning of the rule of law and democratic processes in the EU and its Member States , 2021 update“. http://www .europarl.europa.eu/RegData/etudes/STUD/2021/653633/EXPO_STU(2021)65363 3_EN.pdf 
outside (the pandemic) crisis? If yes, this would bring online platforms' services a big step closer to that of media providers. Facebook News services are, similarly, a type of content aggregation that has been selected and promoted by the platform. ${ }^{39}$ Questions of responsibility and accountability for these remain.

An extreme interpretation of this liberal approach has been taken regarding search engines in the US.40 It has been argued that Baidu, or Google, have First Amendment rights to select and edit the search results of their users.

This selection and sorting is "a mix of science and art" and a way of "how each search engine company tries to keep users coming back to it rather than to its competitors". ${ }^{41}$ In this logic, it is entirely users' risk whether the search results are trustworthy. The monopolistic status of search engines may provide a new perspective. Liability for generating own content is less ambiguous; platforms would bear content providers' liability (rather than hosting providers' only). Proposed measures under the draft Digital Markets Act (DMA) ${ }^{42}$ would prohibit gatekeepers from giving their own content priority in the ranking (Article 6.1.d. DMA), but gatekeepers would nevertheless still be allowed to provide such services.

German case law also provides examples for this more liberal approach. Their main line of argument is that platforms' TOS may set the "house rules" of the company as a result of their freedom of entrepreneurship (Article 12 of the German Basic Law). Those rules may depart from the Constitution and may restrict content that would otherwise be protected by the right to freedom of expression. ${ }^{43}$ These rules should, however,

39 Facebook News, 'Introducing Facebook News'.

40 Eric Goldman, "Of Course The First Amendment Protects Baidu's Search Engine, Even When it Censors Pro-Democracy Results", Forbes Cross-Post (blog), Technology and Marketing Law Blog, March 28, 2014, https:/www.forbes.com/sites/e ricgoldman/2014/03/28/of-course-the-first-amendment-protects-baidus-search-engi ne-even-when-it-censors-pro-democracy-results/?sh=1d21a62b4ec8.

41 Eugene Volokh and Donald Falk, "Google - First Amendment Protection for Search Engine Search Results”, UCLA School of Law Research Paper No. 12-22, April 10, 2012, http://dx.doi.org/10.2139/ssrn.2055364.

42 Proposal for a Regulation of the European Parliament and of the Council on contestable and fair markets in the digital sector (Digital Markets Act) (2020), https://eur-lex.europa.eu/legal-content/en/TXT/?uri=COM\%3A2020\%3A842\%3AF IN.

43 OLG Karlsruhe, 28.02.2019 - 6 W 81/18, NJW-RR 2019, 1006; LG Frankfurt/Main, 10.09.2018 - 2-03 O 310/18, MMR 2018, 770; See also: Daniel Holznagel, "Put-back- Ansprüche gegen soziale Netzwerke: Quo vadis?”, (2019) 8 CR 
still be subject to the German Civil Code, which provides for principles of fairness concerning general TOS (see above). Their respective market power impacts the evaluation of the TOS, as monopolistic companies owe a higher level of responsibility to provide fair conditions. This brings us to the enhanced responsibility of those companies whose services are comparable to a public function (see below).

\section{Chapter 3. The bigger picture}

As mentioned, the two schools of interpretation are not strictly separate in reality. Systemic-level regulatory approaches would be able to connect them, acting as an umbrella. One umbrella approach is infrastructural regulation (3a). The other is the emerging interpretation of the direct applicability of international human rights $(3 \mathrm{~b})$. Both perspectives understand online platforms to be uniquely powerful actors of the global market and are therefore expected to apply primarily to very large market players.

\section{Chapter 3.a. Infrastructural regulatory approach}

Infrastructural regulation may serve as a bridge between the two schools of interpretation. Legal acknowledgement of some platforms' dominant status on the market leads to passing rules on interoperability and regulating the contracting terms of these actors. In the European Union, the Digital Markets Act has gone this direction by defining 'gatekeepers' and imposing on them the obligation to apply fair contractual terms with their business users (Article 5-6 DMA). There is discussion of treating platforms as public utilities in the US, comparing them to a range of industries, from railroads to certain media outlets, in the position of a gatekeeper. ${ }^{44}$ This perspective may lead to antitrust considerations and rules of interoperability.

This approach may not appear to relate directly to content regulation and users' rights; however, the search for the appropriate role of online

35, no. 8 (2019): 518-526; Matthias Friehe, "Löschen und Sperren in sozialen Netzwerken”, NJW 73, no. 24 (2020): 1697-1702.

44 Nikolas Guggenberger, "Essential Platforms", Yale Law \& Economics Research Paper 24, no. 2 (2020): 237-343, https://ssrn.com/abstract=3703361 or http://dx.doi .org/10.2139/ssrn.3703361. 
platforms is a search for the appropriate power balance in a market where private corporations control access to services that are becoming vital to society. ${ }^{45}$ Not only are broadband internet, finances, and e-commerce vital, but so is participation in online communities. The market power and monopoly status of a service provider have a crucial impact on users not only as consumers but also as citizens. It directly affects their fundamental right to receive and impart information (Article 10 ECHR, Article 11 Charter of Fundamental Rights of the European Union, Article 19 ICCPR).

\section{Chapter 3.b. Horizontal effect of human rights}

The analogy to public utilities also raises questions about contracting obligations. For example, are online platforms entitled to ban anyone permanently from their services? A German court assessed this question and found that Facebook has no obligation to conclude a contract, even if they are in a monopolistic position. ${ }^{46}$ However, their dominance may impact how the Terms of Services are judged (see above). In another case, the Constitutional Court found that where excluding a user from services would significantly influence that user's social participation, the service provider may only do so under certain conditions and when respecting safeguards. Among these, the service provider must respect the right to a fair trial, allow a hearing and give reasons for decisions. This ruling related to a ban from sports establishments for extremist behaviour, and it is undecided whether it applies to platform media as well. ${ }^{47}$

Suspension of a user account has become a central issue after Facebook and Twitter suspended the account of US President Donald Trump for posts that were regarded as inciting violence during an attack on the Capi-

45 K. Sabeel Rahman, "The New Utilities: Private Power, Social Infrastructure, and the Revival of the Public Utility Concept”, Cardozo Law Review 39, no. 5 (2018): 1621-1692.

46 LG Görlitz, 29.11.2019 - 1 O 295/19 EV, MMR 2020, 196; OLG Dresden, 16.06.2020 - 4 U 2890/19, MMR 2021, 58.

47 Judgment of the German Constitutional Court, BVerfG, 11.04.2018 - 1 BvR 3080/09, Stadionverbot, NJW 2018, 1667. 
tol. ${ }^{48}$ The much-debated decision was referred to the Facebook Oversight Board for a decision on its lawfulness.

The Facebook Oversight Board was established by the largest social media platform to interpret and decide standards for the platform. The platform commissions the Board members, but its organisation is independent. The Charter of the Board stipulates its competences and defines the extent of Facebook's obligation to follow its decisions. ${ }^{49}$ Thus, the quasi-authoritative body gives the impression of independent oversight, supported by the diversity and competence of its members, but it is in fact part of the platform's voluntary self-regulation. (See a critical analysis of the construction by Mårten Schultz in this volume).

In its decision about Donald Trump, ${ }^{50}$ the Board found that the decision to suspend his account was justified. However, the terms of contract and Community Standards of the platform provided for either definite-period suspension or ultimate exclusion from the platform. Suspension for an indefinite period, in the absence of criteria defining whether and when the account will be reinstated, violated these terms and standards. The Board did not overrule Facebook's decision on the merits of suspension but instead referred the case back for review and gave principles to guide the new decision. ${ }^{51}$

When discussing the roles and obligations of platforms to their users, the question of whether platforms are subject to human rights obligations inevitably emerges. The Facebook Oversight Board relies on principles of public international law in its decision-making. Facebook asserted it is bound by the UN Guiding Principles on Business and Human Rights (UNGPs) in March 2021. Additionally, the Board also referred to the Rabat Plan of Action, General Comment No. 34 of the Human Rights Committee (2011), and the UN Special Rapporteur's report on freedom of opinion and expression A/HRC/38/35 (2018).

48 "The Capitol Attack Was the Most Documented Crime in History. Will That Ensure Justice?”, Time, 9 April 2021, https://time.com/5953486/january-capitol-att ack-investigation/.

49 Oversight Board Charter, https://about.fb.com/wp-content/uploads/2019/09/overs ight_board_charter.pdf.

50 Decision 2021-001 FB-FBR, https://www.oversightboard.com/decision/FB-691QA $\mathrm{MHJ}$.

51 Judit Bayer, "The Power of Softness, The Trump Decision of the Facebook Oversight Board”, Inforrm's Blog, May 11, 2021, https://inforrm.org/2021/05/11/the-po wer-of-softness-the-trump-decision-of-the-facebook-oversight-board-judit-bayer/. 
German jurisprudence has a clear stance on this issue. Since the Lüth case, ${ }^{52}$ German Basic Law is held to have an indirect effect on individuals as third parties in relation to private entities (indirect third-party effect). This has been reinforced by several decisions, as cited above, which declared that online platforms, although not directly bound by the Basic Law, should respect its principles on fundamental rights. ${ }^{53}$ However, the exact extent of this legal requirement has not yet been conclusively discussed. ${ }^{54}$ Hungarian constitutional case law also holds that the state has a positive obligation to ensure the necessary conditions for democratic public opinion to remain operative, ${ }^{55}$ for example, through public service media. 56

In contrast to the European approach, the US posits that private entities are not bound by the Constitution as a result of the state action doctrine. ${ }^{57}$ With a few exceptions, ${ }^{58}$ the US courts generally reject the idea that private entities would be bound to respect human rights. ${ }^{59}$

International human rights bodies take the view that states are obliged to ensure the protection of human rights even vis-a-vis private entities. This means that individuals are entitled to seek redress against perceived violations by private entities. Therefore, states owe a responsibility under international law to prevent, punish and remediate human rights violations by private entities. ${ }^{60}$ Jørgensen and Zuleta argue that the UN appears

52 BVerfG, 15.01.1958 - 1 BvR 400/51.

53 LG Frankfurt/Main, 10.09.2018 - 2-03 O 310/18, MMR 2018, 770; , LG Frankfurt/Main, Beschluss vom 14.05.2018 - 2-03 O 182/18, MMR 2018, 545; see also BVerfG Lüth-Urteil, 15.01.1958 - 1 BvR 400/51, NJW 1958, 257.

54 Jörn Reinhardt and Melisa Yazicioglu, "Grundrechtsbindung Und Transparenzpflichten Sozialer Netzwerke”, Den Wandel Begleiten - IT-Rechtliche Herausforderungen Der Digitalisierung, 2020, 819.

55 Hungarian Constitutional Court, 30/1992. (V. 26.).

56 László Majtényi, Máté Szabó, Alkotmányjog (Eötvös Károly Közpolitikai Intézet, 2005). https://regi.tankonyvtar.hu/hu/tartalom/tkt/alkotmanyjog/index.html

57 Amélie Heldt, "Trump's Very Own Platform? Two Scenarios and Their Legal Implications”, JuWissBlog, January 11, 2021, https:/www.juwiss.de/03-2021/.

58 Marsh v. Alabama, 326 U.S. 501 (1946), https://supreme.justia.com/cases/federal/u s/326/501/; PruneYard Shopping Center v. Robins, 447 U.S. 74 (1980), https://sup reme.justia.com/cases/federal/us/447/74/.

59 See this in detail by: Amélie Heldt, "Merging the Social and the Public: How Social Media Platforms Could be a New Public Forum" Mitchell Hamline Law Review 46, no. 5 (2020): https://ssrn.com/abstract=3460067.

60 UNHR Committee, General Comment no. 31. The nature of the general legal obligation imposed on state parties to the Covenant, (CCCPR/C/21/Rev.1./ Add.13) 2004, para. 8 (p.54-55). 
to foster the view that human rights standards apply to companies. Rather than owing direct responsibility, however, their obligation is akin to the "risk assessment" method (see below). ${ }^{61}$

The Council of Europe takes a pro-active attitude in this respect. Under the European Convention on Human Rights, states are obliged to prevent, protect, and remediate human rights violations by private entities. Moreover, the Committee of Ministers is occupied with the issue of the human rights responsibilities of private corporations. In its 2012 Recommendation on the Protection of Human Rights with Regard to Social Networking Services, the Committee called upon online intermediaries to "respect human rights and the rule of law" by implementing self- and co-regulatory mechanisms, including procedural safeguards and accessible, effective remedies. ${ }^{62}$ Further, it explicitly referred to the UN Guiding Principles in its 2014 Recommendation as a guide to human rights for Internet users, and suggested that platforms should respect the standards of the European Convention on Human Rights (ECHR) in their content removal, deletions and suspensions of user accounts. ${ }^{63}$ The EU Charter of Fundamental Rights also seems to have horizontal effect, as shown by a decision of the Court of Justice of the European Union (CJEU) ${ }^{64}$ and academic authors. ${ }^{65}$

Under the European Court of Human Rights (ECtHR) case law, states have a positive obligation to actively promote pluralism in society and the

61 Rikke Frank Jørgensen and Lumi Zuleta, "Private Governance of Freedom of Expression on Social Media Platforms", Nordicom Review 41, no. 1 (2020): 5167, https://doi.org/10.2478/nor-2020-0003.

62 Recommendation CM/Rec (2012)4 of the Committee of Ministers on the Protection of Human Rights with Regard to Social Networking Services.

63 Recommendation CM/Rec (2014)6 of the Committee of Ministers on a guide to human rights for Internet users suggests that platforms should respect the standards of the ECHR in their content removal and account for removal decisions, at 53.

64 Joined cases C-569/16 and C-570/16 Stadt Wuppertal v. Maria Elisabeth Bauer and Volker Willmeroth v. Martina Broßonn, Judgment of 6 November 2018, discussed by Dorota Leczykiewicz, "The Judgment in Bauer and the Effect of the EU Charter of Fundamental Rights in Horizontal Situations”, European Review of Contract Law 16, no. 2 (2020): 323-333, https://doi.org/10.1515/ercl-2020-0017.

65 Eleni Frantziou, "The Horizontal Effect of the Charter of Fundamental Rights of the EU: Rediscovering the Reasons for Horizontality”, European Law Journal 21, no. 5 (2015): 657-679, https://fra.europa.eu/en/node/35696. 
media. ${ }^{66}$ This positive obligation extends to ensuring an environment that is favourable to freedom of expression. ${ }^{67}$

States also have a positive obligation to ensure respect for private life (Article 8 ECHR). ${ }^{68}$ In the context of social media, privacy includes autonomy in developing one's social life and online persona, in being seen by others as one chooses to be seen. ${ }^{69}$ However, not all interferences with individual human rights involving online intermediaries would trigger states' positive obligations. ${ }^{70}$

In sum, there is growing academic literature and court practice concerning the horizontal effect of human rights owed by companies, including to respect the rights of individuals. However, its exact interpretation is still in development. ${ }^{71}$

\section{Chapter 4. Conclusion}

Online platforms fulfil a new role in e-business and public communication with significant new characteristics that differentiate them from previously known industry actors. The content ranking, recommending, prioritising, and deprioritising choices of these platforms are currently not addressed by legal rules, even though these decisions have a major impact on users' online experiences. Commercial platforms' activity affects economic pro-

66 Tarlach McGonagle, "The Council of Europe and Internet Intermediaries: A Case Study of Tentative Posturing”, in Human Rights in the Age of Platforms, 242. Edited by Rikke Frank Jørgensen and David Kaye. Cambridge, MA: The MIT Press, 2019.

67 McGonagle, (2019) cites: Dink v. Turkey, nos. 2668/07 and 4 others, September 14, 2010.

68 Marckx v Belgium App, no. 6833/74, S. A No 31 [31] (1979), Đorđević v Croatia App. No. 41526/10 ECHR 2012-V [87]-[88] (2012).

69 See more in: Lorna Woods, "Social media: it is not just about Article 10" in: The Legal Challenges of Social Media, edited by David Mangan, Department of Law, Maynooth University and Lorna E. Gillies, Edinburgh Napier University, UK, Elgar Law, Technology and Society series, 2017.

70 McGonagle, (2019) cites: ECtHR, 2017. Tamiz v. the United Kingdom, No. 3877/14 (2017), para. 82-84. and Pihl v. Sweden, No. 74742/14 (2017).

71 See more on this: McGonagle, (2019), Agnès Callamard, "The Human Rights Obligations of Non-State Actors" in Human Rights in the Age of Platforms, 191, edited by Rikke Frank Jørgensen and David Kaye. Cambridge, MA: The MIT Press, 2019; see also: Gunther Teubner, "Horizontal Effects of Constitutional Rights on the Internet: A Legal Case on the Digital Constitution”, The Italian Law Journal 3, no. 1 (2017): 193-205. 
cesses, whereas social media platforms affect communicative processes. The latter directly impacts the public discourse and, therefore, the democratic processes.

This paper has compared two regulatory approaches. One leaves decisions regarding content governance entirely to the platform. At its extreme, platforms are free to moderate content and remove lawful or carry unlawful content without governmental supervision or interference (notwithstanding judicial orders) (US, CDA 230). In its more moderated form, platforms owe a duty of care but are free to decide how they fulfil this duty of a well-maintained platform (UK, Statutory Duty of Care, see more in this volume by Lorna Woods).

The other approach would define rather precisely what type of content is to be removed or moderated and, in its extreme, would not tolerate the removal of lawful content. However, this extreme version is seen only sporadically. In reality, the approaches are mixed. For example, the EU's Digital Services Act provides for the removal of illegal content upon notice and sets out obligations to respect procedural rights in the notice and removal process. It orders platforms to carry out risk assessments and mitigate risks in a co-regulatory framework (EU, DSA).

Viewed critically, platforms act either as regulators themselves or as vectors of state regulation. The first case raises the suspicion of private censorship, whereas the second attracts the criticism of states' outsourcing censorship. $^{72}$

Finally, the paper examined how private entities can become directly responsible for human rights: by the horizontal effect of human rights and an enhanced responsibility due to their market dominance or, perhaps, by obtaining a public utility status.

In a search to find the best option to ensure the - sometimes conflicting - human rights of users are respected, we find ourselves between a rock and a hard place, having to decide whether we prefer regulation by the state or by private actors.

With political accountability in a democratic system, a state would be better equipped to regulate in a field interwoven with fundamental rights sensitivities. However, this is unpractical in many ways due to the vast amount of content, cultural diversity of users, and fast development of

72 Marc J. Bossuyt, Guide to the "Travaux préparatoires" of the International Covenant on Civil and Political Rights, Leiden, Dordrecht: Martinus Nijhoff, 1987, 385. See also: Molly K. Land (2013) "Toward an International Law of the Internet”, Harvard Law Review 54, no. 2 (2013): 393, 445; see also: Callamard (2019). 
technology. Further, in many authoritarian states, online platforms bring a fresh breeze of liberalism and ensure freedoms that could not otherwise be exercised.

Online social participation has become an indispensable necessity for many. Like so many achievements of civilisation, from clean water to education, it is possible but not desirable or acceptable for one to live without access to social platforms. However, the unregulated and unaccountable power of online platforms may lead to arbitrary decisions affecting citizens in ways that are seen as disproportionate.

There is one agreeable point between the various approaches: the standards pledged by online platforms themselves are contractual terms, or "house rules", and should be abided by as a minimum.

\section{Bibliography}

Bayer, Judit, Natalija Bitiukova, Petra Bard, Judit Szakács, Alberto Alemanno, and Erik Uszkiewicz. "Disinformation and Propaganda - Impact on the Functioning of the Rule of Law in the EU and Its Member States." HEC Paris Research Paper No. LAW-2019-1341, Update 2020.

Bayer, Judit. "The Power of Softness, The Trump Decision of the Facebook Oversight Board." Inforrm's Blog, May 11, 2021.

Bossuyt, Marc J. Guide to the "Travaux préparatoires" of the International Covenant on Civil and Political Rights, Leiden, Dordrecht: Martinus Nijhoff, 1987.

Callamard, Agnès. "The Human Rights Obligations of Non-State Actors." In Human Rights in the Age of Platforms, 191. Edited by Rikke Frank Jørgensen and David Kaye. Cambridge, MA: The MIT Press, 2019.

Frantziou, Eleni. "The Horizontal Effect of the Charter of Fundamental Rights of the EU: Rediscovering the Reasons for Horizontality." European Law Journal 21, no. 5 (2015): 657-679.

Friehe, Matthias. "Löschen und Sperren in sozialen Netzwerken", NJW 73, no. 24 (2020): 1697-1702.

Gillespie, Tarleton. Custodians of the Internet: Platforms, Content Moderation, and the Hidden Decisions That Shape Social Media. New Haven: Yale University Press, 2018.

Goldman, Eric. "Of Course The First Amendment Protects Baidu's Search Engine, Even When it Censors Pro-Democracy Results", Forbes Cross-Post (blog), Technology and Marketing Law Blog, March 28, 2014. https://www.forbes.com/sites/ericg oldman/2014/03/28/of-course-the-first-amendment-protects-baidus-search-engine -even-when-it-censors-pro-democracy-results/?sh=1d21a62b4ec8.

Guggenberger, Nikolas. “Essential Platforms.” Yale Law \& Economics Research Paper 24, no. 2 (2020): 237-343. 
Heldt, Amelie. "The President and Free Speech: Consequences of Twitter's FactChecking Indication." Internet Policy Review, June 4, 2020.

Heldt, Amélie. "Trump's Very Own Platform? Two Scenarios and Their Legal Implications." JuWissBlog, January 11, 2021.

Heldt, Amélie. "Merging the Social and the Public: How Social Media Platforms Could Be a New Public Forum.” Mitchell Hamline Law Review 46, no. 5 (2020).

Holznagel, Daniel. "Put-back- Ansprüche gegen soziale Netzwerke: Quo vadis?”, (2019) 8 CR 35, no. 8 (2019): 518-526.

Jørgensen, Rikke Frank, and Lumi Zuleta. "Private Governance of Freedom of Expression on Social Media Platforms.” Nordicom Review 41, no. 1 (2020): 5167.

Klonick, Kate. "The Most Important Lesson from the Leaked Facebook Content Moderation Documents." Slate.com, 29.6.2017.

Land, Molly. "Toward an International Law of the Internet." Harvard Law Review 54, no. 2 (2013): 393-458.

Leczykiewicz, Dorota. "The Judgment in Bauer and the Effect of the EU Charter of Fundamental Rights in Horizontal Situations." European Review of Contract Law 16, no. 2 (2020): 323-333.

McGonagle, Tarlach. "The Council of Europe and Internet Intermediaries: A Case Study of Tentative Posturing." In Human Rights in the Age of Platforms, 242. Edited by Rikke Frank Jørgensen and David Kaye. Cambridge, MA: The MIT Press, 2019.

Rahman, K. Sabeel. "The New Utilities: Private Power, Social Infrastructure, and the Revival of the Public Utility Concept." Cardozo Law Review 39, no. 5 (2018): 1621-1692.

Reinhardt, Jörn, and Melisa Yazicioglu. "Grundrechtsbindung Und Transparenzpflichten Sozialer Netzwerke.” In Den Wandel Begleiten - IT-Rechtliche Herausforderungen Der Digitalisierung, 819. Jürgen Taeger, 2020.

Schwär, Hannah and Moynihan, Qayyah. "Instagram and Facebook are intentionally conditioning you to treat your phone like a drug." Business Insider, 05.07.2020.

Schwartmann, Rolf, and Robin Mühlenbeck. "NetzDG Und Das Virtuelle Hausrecht Sozialer Netzwerke.” ZRP, (2020): 170-172.

Teubner, Gunther. "Horizontal Effects of Constitutional Rights on the Internet: A Legal Case on the Digital Constitution.” The Italian Law Journal 3, no. 1 (2017): 193-205. 
